\title{
Unusual case of isolated frontal sinus mycosis after several years of frontal sinus fracture: case report
}

\author{
Demian Manzano Lopez Gonzalez¹, Pablo Rubino²
}

Hospital del Mar. Parc de Salut Mar, Barcelona, Spain and Hospital El Cruce. Dr. Néstor Kirchner, Buenos Aires, Argentina.

\section{ABSTRACT}

Fractures of the frontal sinus account for 5 to $12 \%$ of all the maxillofacial fractures. There are different complications related to frontal sinus fractures and some of them may develop even years after the traumatic episode. Isolated fungal infection of the frontal sinus is very exceptional. The most commonly affected paranasal sinus by fungal infection is maxillary sinus. We present an unusual case of isolated fungal infection of the frontal sinus on an immunocompetent patient who had an old frontal sinus fracture that had happened 70 years before. To the best of our knowledge, this is the first reported case in which these particular circumstances coexist.

\section{KEYWORDS}

Frontal sinus/injuries, seios paranasais, paranasal sinuses diseases, mycosis.

\section{RESUMO}

Caso incomum de micose isolada do seio frontal depois de vários anos da fratura do seio frontal: relato de caso

As fraturas do seio frontal correspondem a 5 a $12 \%$ das fraturas maxilofaciais. Há diferentes complicações relacionadas às fraturas do seio frontal, e algumas delas podem se desenvolver depois de anos do trauma. A infecção fúngica do seio frontal é bastante incomum. O seio paranasal mais comumente afetado por infecções fúngicas é o seio maxilar. Apresentamos um caso incomum de infecção fúngica isolada no seio frontal de um paciente imunocompetente com uma antiga fratura do seio, ocorrida 70 anos antes. Até onde sabemos, este é o primeiro caso relatado da coexistência dessas duas circunstâncias particulares.

\section{PALAVRAS-CHAVE}

Seios frontais/lesões, seios paranasais, doenças dos seios paranasais, micoses.

1 Neurosurgeon, Neurosurgery Department. Hospital del Mar. Parc de Salut Mar, Barcelona, Spain.

2 Neurosurgeon, Neurosurgery Department. Hospital El Cruce. Dr. Néstor Kirchner, Buenos Aires, Argentina. 


\section{Introduction}

Fungal diseases of the paranasal sinuses include allergic fungal sinusitis, fungus balls, acute invasive fungal infection, and chronic invasive fungal infection. Allergic fungal sinusitis and fungus balls are forms of chronic non-invasive fungal infections. Fungus balls are mostly encountered in older immunocompetent patients with a female predominance. Non immunocompetent patients are more exposed to invasive forms of fungal infections. The most commonly affected paranasal sinus by fungal infection is maxillary sinus, followed by ethmoid and sphenoid sinuses. Frontal sinus is often involved secondarily in association with other sinuses. Isolated fungal infection of frontal sinus is very exceptional. ${ }^{1-5}$

Fractures of the frontal sinus represent 5 to $12 \%$ of all the maxillofacial fractures. The most common skull-base complication of these fractures is mucocele and the most potentially serious complication is cerebral spinal fluid (CSF) leak because it involves a risk of central nervous system infection. ${ }^{6,7}$

It is known that a delay in treating fractures of the frontal sinus when indicated is associated with an increased risk of serious infectious complications. ${ }^{8,9}$

It is also a fact that complications concerning frontal sinus fractures may develop even after many years from the traumatic episode. ${ }^{6,7}$

We present an unusual case of isolated frontal sinus fungal infection in an immunocompetent patient, in whom the only pre-existing special condition was an old fracture of the anterior table of the involved frontal sinus that had happened seventy years before.

To the best of our knowledge, this is the first reported case in which these particular circumstances coexist.

\section{Case report}

A 74-year-old immunocompetent patient was referred to us with one week history of spontaneous purulent secretion from the lateral aspect of the right supraciliar region. He presented no history of chronic disease, or any particular medical condition except from an old right frontal sinus fracture due to a horse accident at the age of four. This fracture was limited to the lateral aspect of the anterior frontal sinus table, and never showed any complication. The patient was not able to describe how this fracture had been treated, and no reports on the subject existed. The patient presented a two months history of right frontal headache followed by swelling over the right supraciliar region. The patient was treated with oral antibiotics for a suspected superficial cellulitis but he did not improve, and instead, a purulent secretion appeared on the lateral aspect of the right supraciliar region. This drainage increased when the patient blowed his nose. Cultures from this purulent secretion were negative. The patient, however, never had fever or any systemic affectation, and remained in good general condition throughout the hole process.

A CT-scanner revealed an old right frontal sinus fracture involving the lateral aspect of the anterior table, and communicating the right sinus with the subcutaneous soft tissue. The bone loss could be attributed to the fracture itself or to the erosion effect of the current pathological process. The sinus was filled with an heterogeneous opacity with a few calcified spots and some areas of hyperattenuation. The other paranasal sinuses were free (Figure 1).
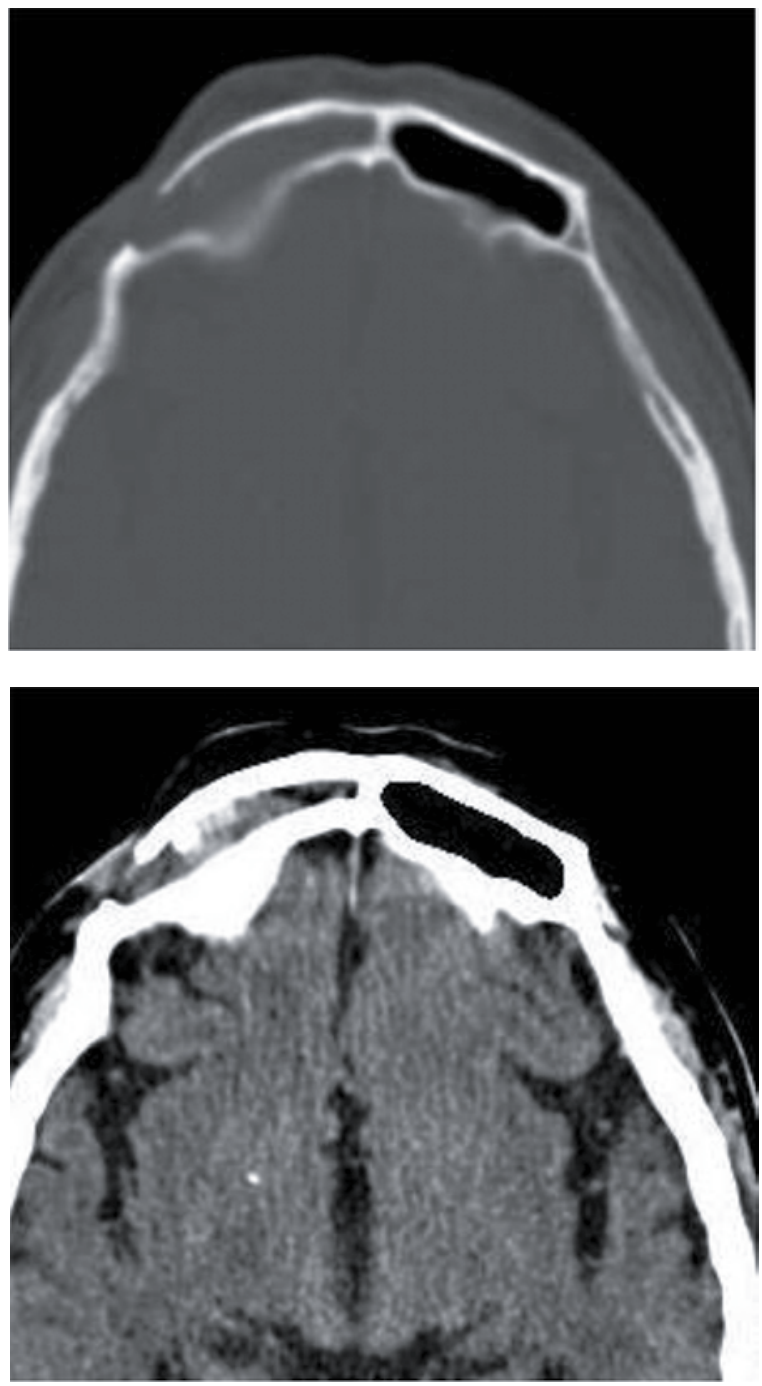

Figure 1 - CT scanner showing a right frontal sinus fracture involving the lateral aspect of the anterior table and communicating the sinus with the subcutaneous soft tissue. The sinus is filled with an heterogeneous opacity with some areas of hyperattenuation. A calcified spot can be seen near the loss of bone on the right sinus. The left frontal sinus is free, as well as the other paranasal sinuses. 
An MR demonstrated iso-hypointenese lesion on T1 occupying the right frontal sinus with extension to the subcutaneous soft tissue through the bone defect. This lesion presented heterogeneous gadolinium enhancement and air bubbles, suggesting infection or less probably a neoplastic process that had communication with external skin (Figure 2).

The patient underwent surgery to remove the lesion, repair the skin defect, and to obtain more samples for histological and microbiological analysis.

A right supraciliary approach to the frontal sinus was performed. A brownish cheesy material was found
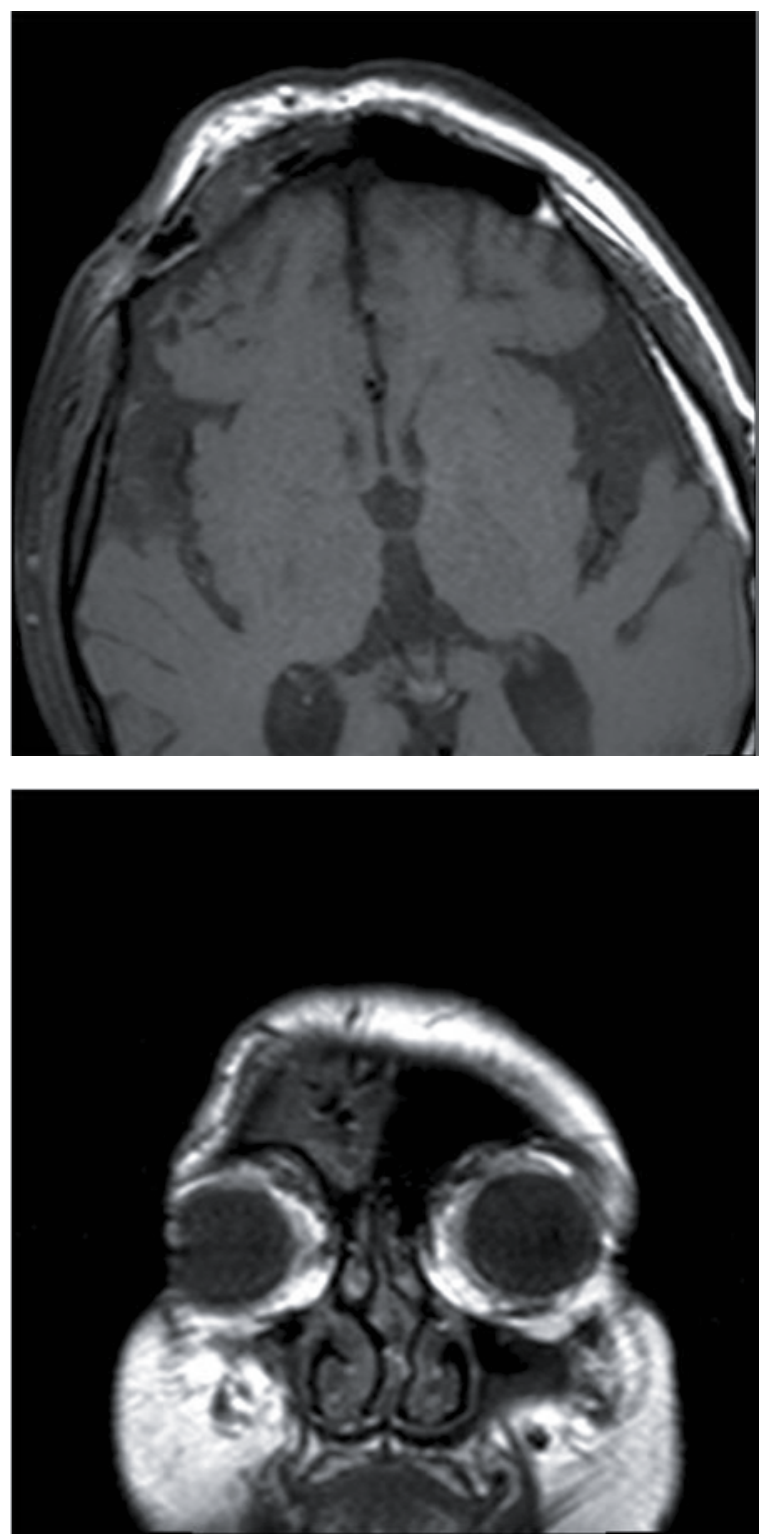

Figure 2 - Axial and coronal views of MR showing iso-hypointense lesion on T1 occupying the right frontal sinus with extension to the subcutaneous soft tissue through the bone defect. The lesion is heterogeneous and has some air bubbles suggesting infection or a neoplastic process that has communication with external skin. filling the frontal sinus. The frontal ostium seemed to be intact. The sinus mucosa was completely removed, and the frontal ostium was obliterated. No sign of bone affectation was found.

Cultures from the obtained material were negative. Hystopathological analysis revealed branching hyphae mass with chronic inflammatory infiltrate composed of plasma cells, neutrophils, and calcification foci. No mucosa invasion was found. These findings confirmed mycosis infection of the frontal sinus, and specifically a fungus ball (Figure 3).

The patient presented good postoperative outcome and was discharged three days later. He received an 8-week oral treatment of posaconazol (following the infectologist's instructions), and showed no complication during the follow-up period.

The MR performed one year later showed postoperative residual changes and no sign of lesion recurrence.

The patient remained asymptomatic and showed no recurrence during the one year follow-up period.

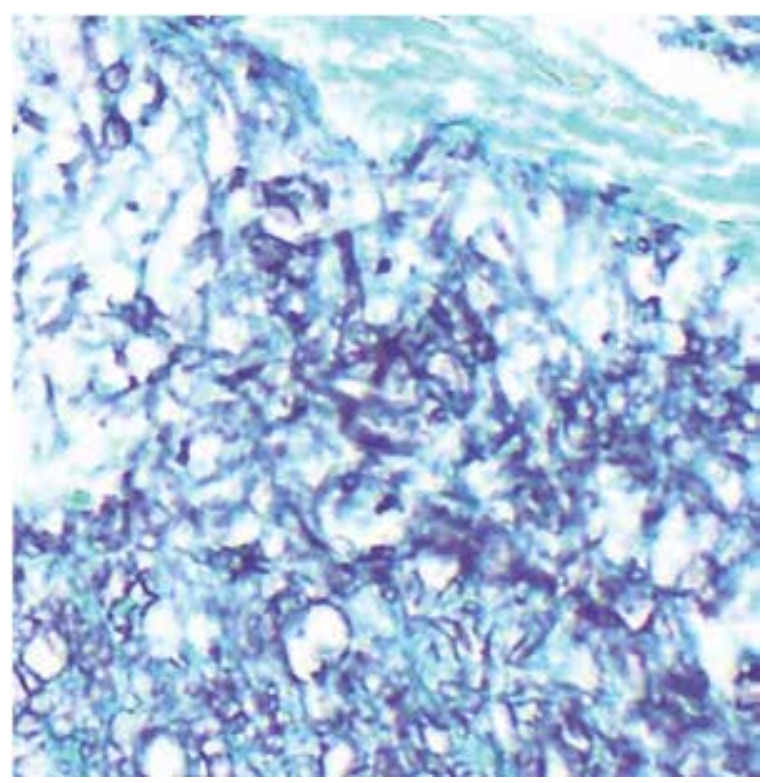

Figure 3 - Photomicrograph showing histopathological findings with Gomori methenamine silver stain. Branching fungal hyphae mass can be seen. There are granulomatous inflammation elements and lack of tissue invasion (which is characteristic of fungus balls).

\section{Discussion}

Fractures of the frontal sinus account for 5 to $12 \%$ of all maxillofacial fractures. They are the cranial fractures most frequently associated with facial fractures. They are generally secondary to motor vehicle accidents but also, and increasingly, associated with personal aggression, sport injuries, falls, and falling objects. ${ }^{10-16}$ 
Complications that may be associated with frontal sinus fractures are: mucocele, mucopyocele, cerebrospinal fluid (CSF) leak, intracranial complications such as intraparenchymal hemorrhage, brain abscess, pneumocephalus, tension pneumocephalus, expanding pneumocephalus, intracerebral pneumatocele, meningitis, encephalitis, cerebral contusion, increased intracranial pressure, chronic headache, ophthalmologic and orbital complications such as decreased visual acuity, blindness, orbital abscess, cellulitis, muscle entrapment, ophthalmoplegia, and maxillofacial complications such as chronic sinusitis, frontal sinus cutaneous fistula, contour deformity, osteomyelitis and local paresthesias or dysesthesias. ${ }^{11,17-22}$

Mucocele is usually related to injury of nasofrontal ostia or nasofrontal ducts that are undiagnosed or poorly treated. If the frontal sinus mucosa gets isolated from nasal cavity, or is left behind after a frontal sinus fracture repair, it may develop a mucocele even after several years. ${ }^{23,24}$

Cerebrospinal fluid leak is a serious complication that may lead to severe intracranial infections if unrecognized or untreated. Most of the time CSF leak is transient, but it may be persistent and require cranialization and dural repair. ${ }^{25,26}$

Management of frontal sinus fractures is controversial due to the possibility of late complications and sequelae. ${ }^{6,7}$ It is generally accepted that the importance of the nasofrontal outflow tract injury, the degree of involvement of the posterior sinus table, and the presence of persistent CSF leak, are important factors that preclude surgical management for these fractures. ${ }^{22,26-36}$ Posterior table fractures with severe comminution, CSF leak, or nasofrontal ostia involvement should be treated with cranialization. If the posterior table is intact and the nasofrontal ostia are damaged, complete removal of the mucosa and obliteration should be performed. If the anterior table is displaced and the posterior table and the nasofrontal ostia are intact, reconstruction should be indicated. ${ }^{6,715,37-41}$ Once indication for surgical management is established, a delay in performing surgery beyond 48 hours is associated with an increased risk of life-threatening infectious complications. To avoid serious infections in these patients, it is advisable to perform surgical intervention as soon as the patient is stable and in reasonable conditions to undergo surgery. Despite the benefit of early surgical intervention, these patients most often present with other and more severe intracranial and body injuries. Thus definitive management is often delayed until the patient's neurological and medical condition has stabilized. ${ }^{8}$

On the other hand, the efficacy of antibiotic prophylaxis beyond the perioperative period in frontal sinus and skull base injury is unclear. Prolonged antibiotic use does not significantly reduce infection risk, and should be reserved for those with other risk factors. ${ }^{8}$

Concerning fungal infections of the frontal sinus some aspects are to be stated.

Fungal diseases of the paranasal sinuses include allergic fungal sinusitis, fungus balls (mycetoma), acute invasive fungal infection, and chronic invasive fungal infection. ${ }^{3,4}$ Allergic fungal sinusitis and fungus balls are forms of chronic non-invasive fungal infections. Fungus balls are mostly encountered in older immunocompetent patients with a female predominance. ${ }^{1-4,42}$ Non immunocompetent patients are more exposed to invasive forms of fungal infections. Aspergillosis is the most common fungal infection of the paranasal sinuses. ${ }^{42-44}$ The most commonly affected paranasal sinus by fungal infection is maxillary sinus, followed by ethmoid and sphenoid sinuses. Frontal sinus is often involved secondarily in association with other sinuses. Isolated fungal infection of frontal sinus is very exceptional, with few reports in the literature. ${ }^{1-5,45}$ The most accepted etiopathogenic mechanism of mycotic infections of the paranasal sinuses is the "aerogenic model" in which inhalation of the fungal spores lead to fungal colonization, and in turn, infection. ${ }^{42,46}$ Those sinuses with a more direct route of access from the nasal cavity are more likely to be involved in these infections. Compared with other paranasal sinuses, frontal sinus has lower susceptibility to fungal infections because its ostium is located in the antero-superior part of the nasal cavity, thus the least accesible part to inhalated spores ${ }^{47}$ The other postulated etiopathogenic mechanism is the "dental model" which is based on orosinusal fistula or perforation of the maxillary sinus by root canal-filling material. ${ }^{46}$ This mechanism was not responsible in the case we present because there had been no previous dental procedures, and the maxillary sinus was not involved.

Clinical presentation of isolated frontal sinus mycosis includes poor nasal symptoms, frontal and periorbital pain, unilateral headache, frontal pressure sensation, and unexplained epistaxis. Anyway, isolated frontal sinus fungal infection is often symptomless until complications such as orbital or intracranial invasion occur. ${ }^{4,5,43,45,48,49}$ In the case we present the patient showed unilateral headache, supraorbital swelling, and finally, a purulent secretion on the lateral aspect of the supraciliar region (which is extremely exceptional and it is not described in the literature).

On CT scanner fungal infection of frontal sinus generally shows heterogeneous expansile lesions with central hyperattenuation. Bony destruction of sinus walls may be present and it is commonly the result of pressure atrophy and dissolution by proteolytic enzymes and cytokines that are produced as part of the inflammatory process. Irregular contrast enhancement 
can be present. Microcalcifications or metallic dense spots associated with sclerosis of the bony wall suggest the presence of a fungus ball. On MR sinus fungal involvement generally shows iso-hypointense lesion on T1 and more hypointense signal on T2. ${ }^{3-5,42,45,50-52}$ The case we present shows bone defect, dense calcified spots in the CT scanner, and low signal on MR. These findings are consistent with frontal sinus fungus ball, specially aspergillosis.

According to the literature only 23-50 per cent of fungus ball cultures are positive, and Aspergillus flavus and A. fumigatus are the usual responsible pathogens. ${ }^{4,5,53}$ In our case the microbiological cultures were negative. Because of the non-specific symptoms and the poor microbiological results, diagnose of isolated frontal fungal infection relays on the radiological and histopathological findings. These include granulomatous inflammation elements, branching fungal hyphae, calcification foci, and lack of tissue invasion (which is characteristic of fungus balls). Special silver technics such as Gomori's Methenamine Silver stain help to reveal the branching hyphae structure, which is of acute angles for Aspergillus. ${ }^{3,54,55}$ These findings were present in our case (Figure 3).

The case we present shows affectation of the anterior table of the right frontal sinus and indemnity of the nasofrontal ostium (which is the presumed way of the infection).

It is certainly difficult to establish a clear relationship between the fracture and the fungal infection in the case we present, especially when there is a gap of 70 years between both circumstances. But the fact is that the only special or anomalous pre-existing condition in this patient is the presence of the fracture of the anterior wall of the frontal sinus. Local tissue damage as well as general immune deficiency facilitate the progression of the colonization of inhaled fungal spores into distinct forms of sinus mycosis (invasive or non-invasive).$^{42}$ The fracture of the anterior wall of the frontal sinus in the case we present can certainly be considered as local tissue damage, and it might have played a role in the occurrence of the fungal infection but it is surprising that it had happened 70 years before, and with no other general or immune deficiency. The fracture did not affect the permeability of the frontal ostium as it could be constated during the surgery, and this is also supported by the fact that the patient did not develop a mucocele as a late complication, and, on the other hand, he did develop a fungal infection. Patency of the nasofrontal ostium is also demonstrated by the presence of secretion through the supraciliar region when the patient blowed his nose. May the fracture and the overlying scar tissue facilitated the drainage of fungal material through the supraciliar region instead of draining through the nasofrontal ostium. However nose secretion or rhinorrhea is not seen in cases of fungus ball sinus involvement, and instead, can be present in the allergic fungal sinusitis forms, which are usually associated with sinus polyposis, raised immunoglobulin E levels, and Charcot-Leyden crystals and allergic mucin on histopathology as well as lack of fungal hyphae within the soft tissues. ${ }^{45}$

Very few cases of isolated fungal infection of the frontal sinus are reported in the literature.

Late complications of frontal sinus fractures can be seen even years after the traumatic episode, but these are usually as mucocele or mucopyocele.

The case we present constitutes an exceptional case in which very unusual circumstances coexist. There is a cranial fungal infection on an immunocompetent patient. There is an isolated frontal sinus involvement. There is a gap of 70 years between the occurrence of the fracture and the fungal infection.

To the best of our knowledge, this is the first reported case in which these particular circumstances coexist.

\section{Competing interests}

The authors declare no conflict of interest.

\section{References}

1. Akpunonu BE, Ansel G, Kaurich JD, Savolaine ER, Campbell EW Jr, Myles JL. Zygomycosis mimicking paranasal malignancy. Am J Trop Med Hyg. 1991;45(3):390-8.

2. Colman MF. Invasive Aspergillus of the head and neck. Laryngoscope. 1985;95(8):898-9.

3. Ferreiro JA, Carlson BA, Cody DT 3rd. Paranasal sinus fungus balls. Head Neck. 1997;19(6):481-6.

4. Popko M, Broglie MA, Holzmann D. Isolated fungus ball mimicking mucocele or frontal sinus tumour: a diagnostic pitfall. J Laryngol Otol. 2010;124(10):1111-5.

5. Panda NK, Ekambar Eshwara Reddy C. Primary frontal sinus aspergillosis: an uncommon occurrence. Mycoses. 2005;48(4):235-7.

6. Metzinger SE, Metzinger RC. Complications of frontal sinus fractures. Craniomaxillofac Trauma Reconstr. 2009;2(1): 27-34.

7. Gabrielli MF, Gabrielli MA, Hochuli-Vieira E, Pereira-Fillho VA. Immediate reconstruction of frontal sinus fractures: review of 26 cases. J Oral Maxillofac Surg. 2004;62(5): 582-6.

8. Bellamy JL, Molendijk J, Reddy SK, Flores JM, Mundinger GS, Manson PN, et al. Severe infectious complications following frontal sinus fracture: the impact of operative delay and perioperative antibiotic use. Plast Reconstr Surg. 2013;132(1):154-62.

9. Luce EA. Discussion: severe infectious complications following frontal sinus fracture: the impact of operative 
delay and perioperative antibiotic use. Plast Reconstr Surg. 2013;132(1):163-4.

10. Manolidis S, Hollier LH Jr. Management of frontal sinus fractures. Plast Reconstr Surg. 2007;120(7 Suppl 2):32S-48S.

11. Metzinger SE, Guerra AB, Garcia RE. Frontal sinus fractures: management guidelines. Facial Plast Surg. 2005;21(3):199-206.

12. Xie C, Mehendale N, Barrett D, Bui CJ, Metzinger SE. 30year retrospective review of frontal sinus fractures: The Charity Hospital experience. J Craniomaxillofac Trauma. 2000;6(1):7-15.

13. Strong EB, Pahlavan N, Saito D. Frontal sinus fractures: a 28-year retrospective review. Otolaryngol Head Neck Surg. 2006;135(5):774-9.

14. Piccolino P, Vetrano S, Mundula P, Di Lella G, Tedaldi M, Poladas G. Frontal bone fractures: new technique of closed reduction. J Craniofac Surg. 2007;18(3):695-8.

15. Haug RH. Management of fractures of the frontal bone and sinus. In: Peterson LJ, Indresano AT, Marciani RD, editors. Principles of oral and maxillofacial surgery. Philadelphia: JB Lippincott; 1992. p. 575.

16. Stevens $\mathrm{M}, \mathrm{Kline} \mathrm{SN}$. Management of frontal sinus fractures. J Craniomaxillofac Trauma. 1995;1(1):29-37.

17. Day TA, Meehan R, Stucker FJ, Nanda A. Management of frontal sinus fractures with posterior table involvement: a retrospective study. J Craniomaxillofac Trauma. 1998;4(3):6-9.

18. Gerbino G, Roccia F, Benech A, Caldarelli C. Analysis of 158 frontal sinus fractures: current surgical management and complications. J Craniomaxillofac Surg. 2000;28(3):133-9.

19. Vrankovic D, Glavina K. Classification of frontal fossa fractures associated with cerebrospinal fluid rhinorrhea, pneumocephalus or meningitis. Indications and time for surgical treatment. Neurochirurgia (Stuttg). 1993;36(2):44-50.

20. Holt GR, Holt JE. Incidence of eye injuries in facial fractures: an analysis of 727 cases. Otolaryngol Head Neck Surg. 1983;91(3):276-9.

21. Chen KT, Chen CT, Mardini S, Tsay PK, Chen YR. Frontal sinus fractures: a treatment algorithm and assessment of outcomes based on 78 clinical cases. Plast Reconstr Surg. 2006;118(2):457-68.

22. Raveh J, Laedrach K, Vuillemin T, Zingg M. Management of combined frontonaso-orbital/skull base fractures and telecanthus in 355 cases. Arch Otolaryngol Head Neck Surg. 1992;118(6):605-14.

23. Wallis A, Donald PJ. Frontal sinus fractures: a review of 72 cases. Laryngoscope. 1988;98(6 Pt 1):593-8.

24. Donald PJ. The tenacity of the frontal sinus mucosa. Otolaryngol Head Neck Surg (1979). 1979;87(5):557-66.

25. Donald PJ, Bernstein L. Compound frontal sinus injuries with intracranial penetration. Laryngoscope. 1978;88(2 Pt 1):225-32.

26. Rohrich RJ, Hollier LH. Management of frontal sinus fractures. Changing concepts. Clin Plast Surg. 1992;19(1):219-32.

27. Weber SC, Cohn AM. Fracture of the frontal sinus in children. Arch Otolaryngol. 1977;103(4):241-4.

28. Choi M, Li Y, Shapiro SA, Havlik RJ, Flores RL. A 10-year review of frontal sinus fractures: clinical outcomes of conservative management of posterior table fractures. Plast Reconstr Surg. 2012;130(2):399-406.

29. Duvall AJ 3rd, Porto DP, Lyons D, Boies LR Jr. Frontal sinus fractures. Analysis of treatment results. Arch Otolaryngol Head Neck Surg. 1987;113(9):933-5.

30. Nahum AM. The biomechanics of facial bone fracture. Laryngoscope. 1975;85(1):140-56.

31. Nahum AM. The biomechanics of maxillofacial trauma. Clin Plast Surg. 1975;2(1):59-64.
32. Gonty AA, Marciani RD, Adornato DC. Management of frontal sinus fractures: a review of 33 cases. J Oral Maxillofac Surg. 1999;57(4):372-9.

33. Rodriguez ED, Stanwix MG, Nam AJ, St Hilaire H, Simmons OP, Christy MR, et al. Twenty-six-year experience treating frontal sinus fractures: a novel algorithm based on anatomical fracture pattern and failure of conventional techniques. Plast Reconstr Surg. 2008;122(6):1850-66.

34. Stanley RB Jr, Becker TS. Injuries of the nasofrontal orifices in frontal sinus fractures. Laryngoscope. 1987;97(6):728-31.

35. Ioannides C, Freihofer HP, Vrieus J, Friens J [corrected to Vrieus J]. Fractures of the frontal sinus: a rationale of treatment. Br J Plast Surg. 1993;46(3):208-14.

36. Ioannides $\mathrm{C}$, Freihofer HP. Fractures of the frontal sinus: classification and its implications for surgical treatment. Am J Otolaryngol. 1999;20(5):273-80.

37. Donald PJ. Frontal sinus ablation by cranialization. Report of 21 cases. Arch Otolaryngol. 1982;108(3):142-6.

38. Piek J. Surgical treatment of complex traumatic frontobasal lesions: personal experience in 74 patients. Neurosurg Focus. 2000;9(1):e2.

39. Ioannides C, Freihofer HP, Bruaset I. Trauma of the upper third of the face. Management and follow-up. J Maxillofac Surg. 1984;12(6):255-61.

40. Godin DA, Miller RH. Frontal sinus fractures. J La State Med Soc. 1998;150(2):50-5.

41. Wolfe SA, Johnson P. Frontal sinus injuries: primary care and management of late complications. Plast Reconstr Surg. 1988;82(5):781-91.

42. Rinaldi V, Portmann D, Boudard P. [Unilateral frontal sinus aspergillosis: the combined endoscopic and minitrephination approach]. Rev Laryngol Otol Rhinol (Bord). 2012;133(2):97-9.

43. Chen IH, Chen TM. Isolated frontal sinus aspergillosis. Otolaryngol Head Neck Surg. 2000;122(3):460-1.

44. Swoboda $\mathrm{H}$, Ullich R. Aspergilloma in the frontal sinus expanding into the orbit. J Clin Pathol. 1992;45(7):629-30.

45. Gupta R, Gupta AK. Isolated primary frontal sinus aspergillosis: role of endonasal endoscopic approach. J Laryngol Otol. 2013;127(3):274-8.

46. De Foer C, Fossion E, Vaillant JM. Sinus aspergillosis. J Craniomaxillofac Surg. 1990;18(1):33-40.

47. Panda NK, Ekambar Eshwara Reddy C. Primary frontal sinus aspergillosis: an uncommon occurrence. Mycoses. 2005;48(4):235-7.

48. Osborn DA. Mycotic infection of the frontal sinus. J Laryngol Otol. 1963;77:29-33.

49. Bhalla D, Kumar S, Pal DN, Malhotra V, Dhingra PL. Aspergilloma of the frontal lobe. Acta Neurochir (Wien). 1980;55(1-2):135-9.

50. Manning SC, Merkel M, Kriesel K, Vuitch F, Marple B. Computed tomography and magnetic resonance diagnosis of allergic fungal sinusitis. Laryngoscope. 1997;107(2):170-6.

51. Dubey A, Patwardhan RV, Sampth S, Santosh V, Kolluri $S$, Nanda A. Intracranial fungal granuloma: analysis of 40 patients and review of the literature. Surg Neurol. 2005;63(3):254-60.

52. Coulthard A, Gholkar A, Sengupta RP. Case report: frontal aspergilloma - A complication of paranasal aspergillosis. Clin Radiol. 1991;44(6):425-7.

53. Popko M, Broglie MA, Holzmann D. Isolated fungus ball mimicking mucocele or frontal sinus tumour: a diagnostic pitfall. J Laryngol Otol. 2010;124(10):1111-5

54. Jayashree P, Puranik R, Kulkarni MH. Cerebral aspergilloma presenting as atypical meningioma in an immunologically 
competent patient: a case report. Indian J Pathol Microbiol. 2007;50(2):367-9.

55. Panigrahi M, Bhiladvale D, Sinha A, Dinakar I. Sclerosing aspergilloma mimicking sphenoid ridge meningioma in an immunologically competent patient. Neurol India. 1998;46:241-3.
Correspondence address

Demian Manzano Lopez Gonzalez

Neurosurgery Department

Hospital del Mar. Parc de Salut Mar

Passeig Maritim 23-25

08003 - Barcelona, Spain

Emails: 95324@parcdesalutmar.cat

dml8923@yahoo.es 